Revue

Revue de l'histoire des religions

del'histoire des religions pendant et frère jumeau d'Israël. Histoire et enjeux

\title{
La représentation juive de l'empire romain comme pendant et frère jumeau d'Israël
}

Avant-propos

Katell Berthelot

\section{OpenEdition}

\section{Journals}

Édition électronique

URL : http://journals.openedition.org/rhr/8550

DOI : $10.4000 /$ rhr.8550

ISSN : 2105-2573

Éditeur

Armand Colin

\section{Édition imprimée}

Date de publication : 1 juin 2016

Pagination : 163-164

ISBN : 978-2-200-93060-8

ISSN : 0035-1423

Référence électronique

Katell Berthelot, «La représentation juive de l'empire romain comme pendant et frère jumeau d'Israël », Revue de l'histoire des religions [En ligne], 2 | 2016, mis en ligne le 01 juin 2016, consulté le 25 septembre 2020. URL : http://journals.openedition.org/rhr/8550; DOI : https://doi.org/10.4000/rhr 8550 


\section{La représentation juive de l'empire romain comme pendant et frère jumeau d'Israël Avant-propos}

L'histoire du peuple d'Israël dans l'Antiquité fut marquée par la confrontation répétée avec de grands empires: empires assyrien, néo-babylonien et perse, royaumes hellénistiques, empire romain. Ce dernier fut-il simplement un empire de plus dans l'histoire d'Israël, ou bien représenta-t-il un défi particulier pour le judaïsme ? C'est la deuxième proposition qui nous semble devoir être retenue, d'une part à cause des succès militaires de Rome, qui dépassaient de loin ce qu'avaient pu réaliser les royaumes hellénistiques divisés, et d'autre part à cause des défaites et des humiliations que l'empire romain infligea aux Juifs suite aux révoltes de 66-70, 115-117 et 132-135 de notre ère, qui eurent pour conséquence la destruction du Temple et de Jérusalem et la fondation d'Aelia Capitolina en lieu et place de la ville sainte. La conjonction entre le succès éclatant des Romains, à qui l'on promettait un « empire sans fin », et la destruction des principaux lieux et symboles qui faisaient l'unité du peuple juif par-delà la dispersion en diaspora, constitua un choc énorme pour la théologie juive.

Si l'empire romain représenta un défi particulier pour Israël, c'est aussi parce qu'il reposait sur l'idée du destin exceptionnel d'un peuple, le peuple romain, à la différence des empires orientaux ou hellénistiques, fondés sur le choix par les dieux d'un souverain et, le cas échéant, de sa lignée. Certes, le principat allait changer la donne en imposant la figure de l'empereur, et nombreux furent les empereurs romains qui reprirent à leur compte des aspects des monarchies hellénistiques. Il n'empêche que c'est au nom 
du peuple romain et de son destin exceptionnel que fut conduite la politique d'expansion et de domination de Rome. De multiples sources littéraires, épigraphiques ou numismatiques répétaient en outre à l'envi que le succès de ce peuple était lié à ses vertus et à la faveur des dieux. D'une certaine manière, d'un point de vue juif, le peuple romain se substituait à Israël comme peuple « élu », destiné à régner sur le monde et à lui apporter la paix.

C'est pourquoi, même si la domination romaine ressembla par certains aspects aux autres dominations vécues par Israël dans l'Antiquité (sur le plan fiscal, par exemple), du point de vue des discours et des représentations, elle était inédite. Le présent dossier explore les sources juives et non-juives qui témoignent d'une représentation juive de Rome comme peuple rival d'Israël, une représentation dont l'aspect le plus central réside sans doute dans l'identification de Rome avec Ésaü, le frère jumeau de Jacob - Israël, et avec la descendance supposée d'Ésaü, les Édomites. La question de l'origine, de l'histoire et des enjeux de cette identification figure par conséquent au cœur de ce dossier. Cependant la construction imaginaire de Rome comme pendant d'Israël ne se limite pas à la figure du jumeau. Elle passe aussi par des récits établissant des liens de symétrie et des correspondances secrètes entre les deux peuples, comme par exemple lorsque des textes rabbiniques affirment que si Rome prospère, Israël est nécessairement en déclin, et vice-versa.

Avec la christianisation de l'empire à partir du IV siècle, la construction de Rome comme peuple rival et même jumeau d'Israël changea progressivement de sens, puisqu'à travers Rome c'est la chrétienté qui fut désignée comme ce frère à la fois proche et menaçant. L'enjeu était d'autant plus complexe que si les Romains des premiers siècles s'intéressaient peu à la Bible, les chrétiens, eux, la lisaient et s'identifiaient depuis longtemps à Jacob - Israël, voire rattachaient les Juifs à Ésaü... L'identité d'Ésaü n'est pas claire dans les sources rabbiniques des $\mathrm{IV}^{\mathrm{e}}-\mathrm{V}^{\mathrm{e}}$ siècles (qui sont de loin les plus nombreuses à documenter l'identification d'Ésaü avec Rome) : s'agit-il de l'empire des premiers siècles, de la chrétienté, ou des deux à la fois ? Ce dossier contribue aussi à éclairer cette question et rejoint ainsi un débat plus vaste, celui de l'impact du christianisme sur la formation du judaïsme rabbinique. 